\title{
THE
}

\section{EPIZOOTIOLOGY OF QUAHOG PARASITE UNKNOWN (QPX) DISEASE IN NORTHERN QUAHOGS (=HARD CLAMS) MERCENARIA MERCENARIA}

\author{
M. MAILLE LYONS \\ ROXANNA SMOLOWITZ \\ Marta Gomez-Chiarri \\ University of Rhode Island, gomezchi@uri.edu
}

Follow this and additional works at: https://digitalcommons.uri.edu/favs_facpubs

Terms of Use

All rights reserved under copyright.

\section{Citation/Publisher Attribution}

Maille, L. M., Smolowitz, R. R., Gomez-Chiarri, M., \& Wand, J. E.. (2007). Epizootiology of Quahog Parasite Unknown (QPX) Disease in Northern Quahogs (=Hard Clams) Mercenaria mercenaria. Journal of Shellfish Research, 26(2), 371-381. doi: 10.2983/0730-8000(2007)26[371:EOQPUQ]2.0.C0;2

Available at: http://dx.doi.org/10.2983/0730-8000(2007)26[371:EOQPUQ]2.0.CO;2

This Article is brought to you for free and open access by the Fisheries, Animal and Veterinary Sciences at DigitalCommons@URI. It has been accepted for inclusion in Fisheries, Animal and Veterinary Sciences Faculty Publications by an authorized administrator of DigitalCommons@URI. For more information, please contact digitalcommons-group@uri.edu. 


\section{EPIZOOTIOLOGY OF QUAHOG PARASITE UNKNOWN (QPX) DISEASE IN NORTHERN QUAHOGS (=HARD CLAMS) MERCENARIA MERCENARIA}

Author(s): M. MAILLE LYONS, ROXANNA SMOLOWITZ, MARTA GOMEZ-CHIARRI, and J. EVAN WARD

Source: Journal of Shellfish Research, 26(2):371-381. 2007.

Published By: National Shellfisheries Association

DOI: http://dx.doi.org/10.2983/0730-8000(2007)26[371:EOQPUQ]2.0.CO;2

URL: http://www.bioone.org/doi/full/10.2983/0730-8000\%282007\%2926\%5B371\%3AEOQPUQ\%5D2.0.CO\%3B2

BioOne (www.bioone.org) is a nonprofit, online aggregation of core research in the biological, ecological, and environmental sciences. BioOne provides a sustainable online platform for over 170 journals and books published by nonprofit societies, associations, museums, institutions, and presses.

Your use of this PDF, the BioOne Web site, and all posted and associated content indicates your acceptance of BioOne's Terms of Use, available at www.bioone.org/page/terms_of_use.

Usage of BioOne content is strictly limited to personal, educational, and non-commercial use. Commercial inquiries or rights and permissions requests should be directed to the individual publisher as copyright holder. 


\title{
EPIZOOTIOLOGY OF QUAHOG PARASITE UNKNOWN (QPX) DISEASE IN NORTHERN QUAHOGS (= HARD CLAMS) MERCENARIA MERCENARIA
}

\author{
M. MAILLE LYONS, ${ }^{1 *}$ ROXANNA SMOLOWITZ, ${ }^{2}$ MARTA GOMEZ-CHIARRI ${ }^{3}$ \\ AND J. EVAN WARD ${ }^{1}$ \\ ${ }^{1}$ Department of Marine Sciences, University of Connecticut, 1080 Shennecossett Road Groton, \\ Connecticut 06340; ${ }^{2}$ Marine Resources Center, Marine Biological Laboratory, 7 MBL Street, \\ Woods Hole, Massachusetts 02543; ${ }^{3}$ Department of Fisheries, Animal and Veterinary Science, \\ University of Rhode Island, 23 Woodward Hall, Kingston, Rhode Island 02881
}

\begin{abstract}
The economically important marine bivalve mollusc, Mercenaria mercenaria, (commonly called a northern quahog or hard clam), has endured considerable mortalities caused by a thraustochytrid pathogen called Quahog Parasite $\mathrm{X}$ (QPX). Data on the percent prevalence of QPX infections were compiled from published reports along with our data to describe the epizootiology of QPX disease. QPX infections occurred in clams collected from both cultured beds and wild populations, but a higher percentage of QPX cases (76.5\%) were from cultured clam beds. In addition, samples from cultured beds had a significantly higher prevalence $(29.2 \pm 27.2 \%)$ of QPX infections compared with samples from wild populations $(9.6 \pm 9.6 \%)$. The highest prevalence of QPX infections occurred in clams from samples with an intermediate size range (shell lengths $20-55 \mathrm{~mm}$ ). QPX infections occurred in both male and female clams, but infection prevalence does not appear to be correlated with sex or sex ratios. The geographical range of QPX-related clam mortalities was Atlantic Canada to the Eastern Shore of Virginia, USA. Only marginally significant differences were detected between the prevalence of QPX at different locations. There were no latitudinal gradients in QPX prevalence or frequencies, suggesting local factors were important in determining its distribution. Although QPX infections occurred throughout the year, no seasonal trends in the prevalence or frequencies of QPX were discernable. This summary of information available on QPX disease highlights the need for more thorough data collection regarding factors believed to be associated with its presence and severity in hard clams.
\end{abstract}

KEY WORDS: Quahog Parasite X (QPX), thraustochytrid, Mercenaria mercenaria, clam, northern quahog

\section{INTRODUCTION}

The commercially important bivalve, Mercenaria mercenaria, (northern quahog or hard clam), has suffered catastrophic mortalities from eastern Canada to coastal Virginia because of a pathogen called Quahog Parasite X (QPX; Whyte et al. 1994, Smolowitz et al. 1998, Ragone-Calvo et al. 1998). QPX is a small (4-120 $\mu \mathrm{m})$, spherical protist, characterized as a thraustochytrid (Whyte et al. 1994, Maas et al. 1999, Ragan et al. 2000, Stokes et al. 2002). In culture (Kleinschuster et al. 1998, Brothers et al. 2000) and in tissue section (Smolowitz et al. 1998), QPX occurs in three life stages: (1) thalli that develop into (2) sporangia that rupture to release (3) endospores (immature thalli). The presence of a fourth stage, zoospores, has not been confirmed (Brothers et al. 2000). In laboratory experiments, cultures of QPX proliferated best at $24^{\circ} \mathrm{C}$, with a $\mathrm{pH} 7-8$ and a salinity of $28 \mathrm{ppt}$ and greater (Brothers et al. 2000).

The QPX organism has been documented in the environment. Positive results have been found for QPX in seawater, marine aggregates, sediments, and in association with invertebrates and macrophytes (Lyons et al. 2005, Lyons et al. 2006, Gast et al. 2006, Gast et al. submitted) using real time PCR (Lyons et al. 2006) and nested PCR followed by DGGE (Gast et al. 2006). The ecology of QPX is not well known, but there is information regarding the ecology of other thraustochytrids (Raghukumar 2002). Thraustochytrids were first described by Sparrow (1936) from a decaying piece of algae. Since then, thraustochytrids have been documented in coastal and oceanic

\footnotetext{
*Corresponding author. E-mail: mmmlyons@hotmail.com
}

waters, in pelagic and benthic habitats, and on plant and animal substrates (Miller \& Jones 1983, Raghukumar et al. 1990, Raghukumar \& Schaumann 1993, Naganuma et al. 1998, Raghukumar \& Raghukumar 1999, Santangelo et al. 2000). Several parasitic associations have been documented for thraustochytrids and molluscs including octopuses, squid, sea hares, abalone, and bivalves (Polglase 1980, McLean \& Porter 1982, Jones \& O’Dor 1983, Bower 1987, Azevedo \& Corral 1997, Anderson et al. 2003). Benign associations have been described for thraustochytrids with salps, sea urchins, corals, hydroids, and sponges (Raghukumar 1988, Frank et al. 1994, Ilan et al. 1996, Raghukumar \& Raghukumar 1999, Thorsen 1999).

The parasite was first designated QPX in a paper by Whyte et al. (1994), which described mass quahog mortalities (occurring since 1989) in a Canadian hatchery on Prince Edward Island. The authors found the parasite to be identical to an unnamed one that caused mass mortalities of wild quahogs in Canada in the early 1960s (Drinnan \& Henderson 1963). From 1990-1998, Canadian researchers monitored cultured hard clam (quahog) beds and hatcheries in New Brunswick, Nova Scotia, and Prince Edward Island (Bacon et al. 1999, MacCallum \& McGladdery 2000) and documented the QPX organism in samples of clams collected from all three Canadian Maritime Provinces.

The first report of an outbreak of QPX disease in the United States was published by Smolowitz et al. (1996) and described a 4-y history of chronic, severe mortalities in cultured hard clams in Provincetown and Duxbury on Cape Cod in Massachusetts. Dying clams were positive for an endosporulating protist similar to the one observed in the Canadian hatchery (Whyte 
et al. 1994). Smolowitz et al. (1998) detailed the gross- and histopathology by comparing observations of the Massachusetts QPX-like organism to the one described by Canadian researchers. Subsequently, United States researchers reviewed archived tissue sections from old cases and discovered that episodic dieoffs in Barnegat Bay, NJ as early as 1976 and high mortalities in the Mitchell River in Chatham, MA around 1992 were also caused by QPX (Smolowitz et al. 1998). Between 1995 and 1998, clam seed from South Carolina that were planted in New Jersey waters suffered significant mortalities from QPX (Ford et al. 2002). Likewise, clam seed from New Jersey that were planted in Massachusetts waters suffered markedly higher levels of QPX disease than clam seed originating from Massachusetts (Smolowitz, unpublished data). Since then, QPX has been detected in New Jersey in wild hard clams from Raritan and Sandy Hook Bays (Ragone-Calvo \& Burreson 2002). In 1996, researchers in Virginia began surveying wild and cultured hard clams (Ragone-Calvo et al. 1997, Ragone-Calvo et al. 1998). Their study was the first to document the presence of QPX in cultured clams as far south as Quinby Inlet on the Atlantic side of Virginia's Eastern Shore. They did not detect QPX in samples of cultured clams from Chesapeake Bay or in any samples from wild populations (Ragone-Calvo et al. 1998). In 2001, QPX was confirmed in Barnstable Harbor, Barnstable, and Pleasant Bay, Orleans, both on Cape Cod in Massachusetts (Hickey et al. 2002). Also in 2001, the first large scale mortalities from QPX disease were observed at a seaside location in Virginia (RagoneCalvo \& Burreson 2002, Camara et al. 2004). In 2002, preliminary testing detected QPX in wild clams from Raritan Bay, NY (Dove et al. 2004). This prompted researchers in New York to survey over 600 clams from 21 sites to document infection prevalence within the bay (Dove et al. 2004). In 2004, QPX was reported in yet another Cape Cod embayment (Wellfleet, MA; Fraser 2004) and in cultured clams from Rhode Island (this report).

To date, the range of QPX-related mass mortalities of hard clams extends north to Canada's Miramichi Estuary of the Gulf of St. Lawrence (MacCallum \& McGladdery 2000) and south to Fisherman's Island on Eastern Shore of Virginia (RagoneCalvo \& Burreson 2002). Within this range, there are clam growing areas that have not experienced mortalities from the QPX pathogen. For example, no QPX was found in samples of cultured clams from the northern or southern shores of Long Island, New York during a 1997-1999 study (Ford et al. 2002). This study reported 1 clam with a light infection from a single sample of wild clams from the Connecticut side of Long Island sound. A later, more intensive survey of wild and cultured clams from 11 sites along Connecticut's coastline revealed no evidence of the presence of QPX (DeCrescenzo et al. 1999) on the northern (Connecticut) side of Long Island Sound. There have been no mass mortalities from QPX documented in Connecticut waters (Sunila 2006).

This analysis combines data from published reports described below with additional QPX disease data from the Marine Biological Laboratory in Massachusetts and the University of Rhode Island. Its purpose is 3-fold. First, we review available data and consolidate information regarding the QPX organism and QPX disease. Second we take an epizootiological approach and evaluate factors that may influence the distribution and severity of QPX disease in hard clams. Finally, we highlight several areas of research that warrant further exploration.

\section{METHODS}

\section{Data Collection}

Data were compiled from several resources. Peer-reviewed published journal articles describing surveys of QPX in clams were available from Canada (Whyte et al. 1994, MacCallum \& McGladdery 2000), Massachusetts (MA; Smolowitz et al. 1998), New York (NY; Ford et al. 1997, Ford et al. 2002, Dove et al. 2004), Connecticut (CT) and New Jersey (NJ; Ford et al. 1997, Ford et al. 2002), and Virginia (VA; Ragone-Calvo et al. 1998, Ragone-Calvo et al. 2007). Information from published conference abstracts and technical reports was also included for Canada (Bacon et al. 1999), MA (Smolowitz et al. 1996, Smolowitz \& Leavitt 1997, Smolowitz \& Leavitt 2001), CT (DeCrescenzo et al. 1999), NJ (Kraeuter et al. 1998), and VA (Ragone-Calvo et al. 1997, Ragone-Calvo \& Burreson 2002, Ragone-Calvo \& Burreson 2003, Ragone-Calvo et al. 2003). Additional, unpublished data for QPX disease were obtained from the Marine Biological Laboratory in Massachusetts (Table 1) and the University of Rhode Island (Table 2).

\section{Data Description}

Histological evaluation was used for determining the presence of QPX in clam tissues (Bower \& McGladdery 2003). Although slight differences between laboratories occurred, in general, clams were shucked, sectioned, fixed, embedded, processed, and stained to make a histological slide (Howard et al. 2004). Individual clams were designated as positive or negative for the presence of QPX. The primary variable in this analysis was percent prevalence of QPX. Prevalence of QPX (percent prevalence, $0-100 \%$ ) was calculated as the number of clams positive for QPX, divided by the total number of clams evaluated in the sample, multiplied by 100 .

This analysis identified 313 samples of clams (averaging $39 \pm$ 26 clams per sample, for a total of more than 11,000 individual clams) that were tested for the presence of QPX, but not all samples included the same type or amount of information (see below). Overall, the 313 samples included data from 1990 (MacCallum \& McGladdery 2000) to 2005 (this study) throughout the range of QPX from Canada (Whyte et al. 1994, MacCallum \& McGladdery 2000) to Virginia (Ragone-Calvo et al. 1998, Ragone-Calvo \& Burreson 2002). Although samples were not collected randomly, they were representative of cultured and wild clams throughout the range of this pathogen over 15 y (1990-2005). A truly random sample is difficult to obtain because of the proprietary nature of the lease sites and the high costs associated with testing.

\section{Data Recoding}

Using epidemiological terminology, "cases" were defined as samples of clams that were positive for QPX infections (i.e., with at least one positive individual clam in the sample) whereas "controls" were defined as samples of clams that were negative for QPX infections. There were approximately two controls $(n=$ 211) for every case $(n=102)$. Data were available for three Canadian Maritime provinces and six US states. After determining that there was no latitudinal gradient (see results, Fig. 2 later), this "location" data was categorized into "country" according to Canadian $(n=115)$ and American $(n=198)$ locations, because 
TABLE 1.

QPX disease data from Marine Biological Laboratory including samples from Massachusetts (MA), Connecticut (CT), and New York (NY). Size recorded as shell length. $(\mathrm{nr}=$ not recorded).

\begin{tabular}{|c|c|c|c|c|c|}
\hline Type of Sample & Sample from & Month of testing & $\begin{array}{l}\text { Mean Size (mm) of } \\
\text { Clams in Sample }\end{array}$ & Number of Clams Tested & $\%$ Prevalence of QPX \\
\hline Cultured bed & MA & January & 44.8 & 67 & 28.0 \\
\hline Cultured bed & MA & February & 46.8 & 24 & 0.0 \\
\hline Cultured bed & MA & February & 52.2 & 146 & 0.0 \\
\hline Cultured bed & MA & April & 42.9 & $\mathrm{nr}$ & 0.0 \\
\hline Cultured bed & MA & April & 24.3 & 60 & 0.0 \\
\hline Cultured bed & MA & April & $\mathrm{nr}$ & 8 & 80.0 \\
\hline Cultured bed & MA & April & 34.2 & 25 & 8.0 \\
\hline Cultured bed & MA & April & 38.7 & 30 & 10.0 \\
\hline Cultured bed & MA & April & 39.3 & 30 & 72.0 \\
\hline Cultured bed & MA & April & 41.6 & 30 & 16.0 \\
\hline Cultured bed & MA & April & 40.3 & $\mathrm{nr}$ & 3.0 \\
\hline Cultured bed & MA & April & 28.1 & 35 & 42.9 \\
\hline Cultured bed & MA & April & 28.8 & 59 & 6.8 \\
\hline Cultured bed & MA & April & 42 & 60 & 21.7 \\
\hline Cultured bed & MA & June & 43.9 & 63 & 0.0 \\
\hline Cultured bed & MA & June & 15.3 & 100 & 0.0 \\
\hline Cultured bed & MA & June & 40.3 & 28 & 43.0 \\
\hline Cultured bed & MA & June & 40.1 & 35 & 44.0 \\
\hline Cultured bed & MA & June & 34.3 & 60 & 12.0 \\
\hline Cultured bed & MA & June & 44.2 & 62 & 16.0 \\
\hline Cultured bed & MA & June & 15.5 & 100 & 2.0 \\
\hline Cultured bed & MA & June & 39.7 & 100 & 100.0 \\
\hline Cultured bed & MA & August & 17.6 & $\mathrm{nr}$ & 0.0 \\
\hline Cultured bed & MA & August & 13.7 & 24 & 0.0 \\
\hline Cultured bed & MA & August & 20.2 & 18 & 0.0 \\
\hline Cultured bed & MA & August & 38.1 & 25 & 0.0 \\
\hline Cultured bed & MA & August & 24.1 & 59 & 3.0 \\
\hline Cultured bed & MA & August & 30.1 & 21 & 52.4 \\
\hline Cultured bed & MA & August & 36.8 & 25 & 32.0 \\
\hline Cultured bed & MA & August & 48.6 & 21 & 28.6 \\
\hline Cultured bed & MA & September & 41.3 & 54 & 0.0 \\
\hline Cultured bed & MA & October & 22.3 & 60 & 0.0 \\
\hline Cultured bed & MA & October & 42.4 & 120 & 2.0 \\
\hline Cultured bed & MA & October & 48.1 & 150 & 4.0 \\
\hline Cultured bed & MA & October & 39.9 & 120 & 7.0 \\
\hline Cultured bed & MA & October & 28.1 & 60 & 15.0 \\
\hline Cultured bed & MA & October & $\mathrm{nr}$ & 53 & 60.0 \\
\hline Cultured bed & MA & October & 42.1 & 30 & 90.0 \\
\hline Cultured bed & MA & November & 20.1 & 25 & 0.0 \\
\hline Cultured bed & MA & November & 27 & 25 & 0.0 \\
\hline Cultured bed & MA & November & 35.9 & 25 & 0.0 \\
\hline Cultured bed & MA & November & 51.5 & 26 & 0.0 \\
\hline Cultured bed & MA & November & 40.9 & 59 & 0.0 \\
\hline Cultured bed & MA & November & 54.4 & $\mathrm{nr}$ & 0.0 \\
\hline Cultured bed & MA & November & 63.0 & 60 & 0.0 \\
\hline Cultured bed & MA & November & 39.4 & 25 & 4.0 \\
\hline Cultured bed & MA & November & 37.4 & 27 & 29.6 \\
\hline Cultured bed & MA & November & 41.9 & 67 & 8.0 \\
\hline Cultured bed & MA & November & 42.3 & 73 & 36.0 \\
\hline Cultured bed & MA & November & 43.6 & 60 & 28.0 \\
\hline Cultured bed & MA & November & 45.2 & 71 & 29.0 \\
\hline Cultured bed & MA & November & $\mathrm{nr}$ & 72 & 80.0 \\
\hline Cultured bed & MA & December & 15.7 & 60 & 0.0 \\
\hline Cultured bed & MA & December & 46.0 & 65 & 0.0 \\
\hline Cultured bed & MA & December & 47.0 & 76 & 0.0 \\
\hline Cultured bed & MA & December & 38.1 & 18 & 100.0 \\
\hline Cultured bed & MA & December & 35.5 & 21 & 100.0 \\
\hline
\end{tabular}


TABLE 1.

continued

\begin{tabular}{|c|c|c|c|c|c|}
\hline Type of Sample & Sample from & Month of testing & $\begin{array}{l}\text { Mean Size (mm) of } \\
\text { Clams in Sample }\end{array}$ & Number of Clams Tested & $\%$ Prevalence of QPX \\
\hline Cultured bed & MA & December & 39.3 & 28 & 90.0 \\
\hline Cultured bed & MA & December & 37.4 & 35 & 12.0 \\
\hline Cultured bed & MA & December & 34.1 & 60 & 12.0 \\
\hline Cultured bed & MA & December & 42.4 & 66 & 36.0 \\
\hline Cultured bed & MA & December & 43.3 & 86 & 8.0 \\
\hline Cultured bed & MA & December & 40.9 & 114 & 3.0 \\
\hline Wild population & $\mathrm{CT}$ & April & 73.6 & 60 & 0.0 \\
\hline Wild population & $\mathrm{CT}$ & August & 53.5 & 40 & 0.0 \\
\hline Wild population & $\mathrm{CT}$ & August & 55.9 & 20 & 0.0 \\
\hline Wild population & $\mathrm{CT}$ & November & 56.3 & 30 & 0.0 \\
\hline Wild population & $\mathrm{CT}$ & November & 61.4 & 30 & 0.0 \\
\hline Wild population & MA & January & 46.0 & 90 & 4.0 \\
\hline Wild population & NY & April & 50 & 20 & 0.0 \\
\hline Wild population & NY & April & 52.3 & 20 & 0.0 \\
\hline Wild population & NY & April & 56.5 & 20 & 0.0 \\
\hline Wild population & NY & August & 43.3 & 20 & 5.0 \\
\hline Wild population & NY & August & 43.4 & 20 & 15.0 \\
\hline Wild population & NY & August & 45.2 & 20 & 5.0 \\
\hline Wild population & NY & November & 45.6 & 20 & 0.0 \\
\hline Wild population & NY & November & 49.5 & 20 & 0.0 \\
\hline Wild population & NY & November & 46.5 & 20 & 15.0 \\
\hline
\end{tabular}

differences in the manifestation of QPX disease for these countries have been noted (Smolowitz et al. 1998, Ragone-Calvo et al. 1998). Data were available for all 12 months, but some months had fewer than 10 observations; therefore, month of testing was also regrouped into "season" as follows: winter (December, January, and February; $n=28$ ), spring (March, April, and May; $n=69$ ), summer (June, July, and August; $n=$ 123), and fall (September, October, and November; $n=91$ ). Two of the samples were yearly averages and did not include month of testing (total $n=311$ ). All samples of clams were collected from either cultured lease sites $(n=197,63 \%)$ or wild populations $(n=$ $116,37 \%)$. Of the 313 samples, $276(88 \%)$ included information on the size of the clams tested for QPX infections. Sizes of clams in the samples were usually reported as length (longest dimension), but sometimes height (umbo to shell edge) and valve width. To compare size measurements between studies, some data were systematically recoded as follows. Whenever available, length was used as the measure of size. If height was the only reported measure of clam size, it was converted to length by multiplying height by 1.14 (Archambault et al. 2004). If the mean size was reported, then the mean size was used in the analysis. If only the range of sizes was listed (i.e., only the minimum and maximum sizes for the smallest and largest clams), then the mean size for that sample was estimated by averaging the minimum and maximum sizes for the clams reported. For some reports $(\sim 9 \%$ of compiled data set) size was reported as "less than" or "greater than" a particular value (e.g., $>25 \mathrm{~mm}$ ). For these samples, the reported value (e.g., $25 \mathrm{~mm}$ ) was used as a conservative estimate for the size of clams in that sample. Only $45(14 \%)$ of the 313 samples included any information regarding sex of the clams, but the data were not in comparable formats. For example, some studies reported the sex ratio of all clams tested, whereas others only reported sex ratios of the clams that tested positive for QPX infections. Consequently, this independent variable was not included in the overall analysis because only 20 samples $(\sim 6 \%$ of the compiled data set) included comparable information.

In summary, the four independent variables evaluated in this analysis were (1) location from which the sample was obtained, both as state/province and country; (2) month and season during which the sample was tested; (3) type of sample (i.e., clams obtained from a cultured bed or a wild population); and (4) mean size (shell length) of clams in each sample. Clam sex was only evaluated for the data in Table 2 .

\section{Statistical Analysis}

In the overall analysis, associations between the frequencies of positive results (cases) and negative results (controls) for location, month, season, and type of sample were evaluated based on the counts for each category with nonparametric ChiSquare tests of independence $\left(\chi^{2}\right)$. Yates continuity corrections were used for $2 \times 2$ contingency tables. Fisher's Exact test was used when category sizes were small or the expected minimum counts were less than 5 . In all cases the null hypothesis $\left(\mathrm{H}_{\mathrm{o}}\right.$ : There was no difference between observed and expected counts) assumed an even distribution of results among categories. For a more detailed analysis of the positive QPX prevalence results, prevalence data were log-odds (logit) transformed to account for the zero-bounded, positively skewed distribution. The transformation resulted in a normal distribution (data not shown), which satisfied the normality assumption for univariate ANOVA's and $t$-tests to compare mean differences in prevalence of QPX. SPSS software was used for transformations and statistical analyses.

\section{RESULTS}

In addition to data from published reports, 78 new samples from the Marine Biological Laboratory (Table 1) and 26 new 
TABLE 2.

QPX disease data from the University of Rhode Island. All samples were from RI. Size recorded as shell length. (nr = not recorded).

\begin{tabular}{|c|c|c|c|c|c|c|c|}
\hline Type of Sample & Month Tested & $\begin{array}{l}\text { Mean Size }(\mathrm{mm}) \text { of } \\
\text { Clams in Sample }\end{array}$ & $\begin{array}{c}\text { Number of Clams } \\
\text { Tested }\end{array}$ & \% Male & $\%$ Female & \% Unknown & $\%$ Prevalence of QPX \\
\hline Cultured bed & May & 23.2 & 30 & $\mathrm{nr}$ & $\mathrm{nr}$ & $\mathrm{nr}$ & 0.0 \\
\hline Cultured bed & May & 18.7 & 30 & $\mathrm{nr}$ & $\mathrm{nr}$ & $\mathrm{nr}$ & 0.0 \\
\hline Cultured bed & May & 25.2 & 27 & $\mathrm{nr}$ & $\mathrm{nr}$ & $\mathrm{nr}$ & 0.0 \\
\hline Cultured bed & May & 19.3 & 30 & $\mathrm{nr}$ & $\mathrm{nr}$ & $\mathrm{nr}$ & 0.0 \\
\hline Cultured bed & June & 13.3 & 12 & 50.0 & 0.0 & 33.3 & 0.0 \\
\hline Cultured bed & June & 25.0 & 25 & 4.0 & 0.0 & 96.0 & 0.0 \\
\hline Cultured bed & June & 26.2 & 6 & 66.7 & 0.0 & 16.7 & 0.0 \\
\hline Cultured bed & June & $\mathrm{nr}$ & 15 & 6.7 & 6.7 & 73.3 & 0.0 \\
\hline Cultured bed & June & 45.5 & 26 & 23.1 & 50.0 & 26.9 & 30.8 \\
\hline Cultured bed & June & 47.8 & 25 & 36.0 & 48.0 & 16.0 & 20.0 \\
\hline Cultured bed & June & 50.4 & 25 & 36.0 & 48.0 & 16.0 & 24.0 \\
\hline Cultured bed & June & 51.9 & 25 & 40.0 & 36.0 & 20.0 & 20.0 \\
\hline Cultured bed & June & 54.7 & 26 & 65.4 & 30.8 & 3.6 & 42.3 \\
\hline Cultured bed & June & 65.4 & 26 & 40.0 & 44.0 & 16.0 & 16.0 \\
\hline Cultured bed & July & 62.1 & 60 & 43.3 & 35.0 & 21.7 & 0.0 \\
\hline Cultured bed & September & 39.2 & 26 & 44.0 & 46.0 & 10.0 & 8.0 \\
\hline Cultured bed & September & 55.3 & 25 & 46.0 & 42.0 & 12.0 & 16.0 \\
\hline Cultured bed & October & 65.5 & 12 & 40.7 & 59.3 & 0.0 & 0.0 \\
\hline Wild population & May & 61.4 & 45 & $\mathrm{nr}$ & $\mathrm{nr}$ & $\mathrm{nr}$ & 0.0 \\
\hline Wild population & May & 62.7 & 15 & $\mathrm{nr}$ & $\mathrm{nr}$ & $\mathrm{nr}$ & 0.0 \\
\hline Wild population & August & 65.9 & 60 & 43.3 & 46.7 & 10.0 & 0.0 \\
\hline Wild population & August & 77.3 & 60 & 46.7 & 43.3 & 10.0 & 0.0 \\
\hline Wild population & August & 94.7 & 30 & 40.0 & 50.0 & 10.0 & 0.0 \\
\hline Wild population & August & 97.5 & 27 & 33.3 & 51.9 & 14.8 & 0.0 \\
\hline Wild population & September & 50.0 & 25 & 36.0 & 62.0 & 2.0 & 0.0 \\
\hline Wild population & September & 67.7 & 6 & 50.0 & 46.0 & 4.0 & 0.0 \\
\hline
\end{tabular}

samples from the University of Rhode Island (Table 2) were included in this analysis.

\section{Clam Size}

The range of clam shell lengths tested for the presence of QPX was $1 \mathrm{~mm}$ to $180 \mathrm{~mm}$ with a mean size of $44.7 \pm 22.8 \mathrm{~mm}$. Although the sample containing the largest clams was positive for QPX (a case), it is not known if the largest clam was positive for QPX. The two smallest sizes of clams testing positive for QPX were reported by Whyte et al. $1994(15-30 \mathrm{~mm})$ and MacCallum \& McGladdery 2000 (18-25 mm), but none of the seed clams $(n=2,303 ; 1-20 \mathrm{~mm})$ tested in Ford et al. (1997) were positive for the presence of QPX. In this analysis, mean size of clams and prevalence of QPX infections were not linearly related, because intermediate sizes appeared to have the highest prevalences (Fig. 1). There was no significant difference in the mean sizes of clams from samples that tested positive (cases; $47.3 \pm 15.2 \mathrm{~mm}, n=90$ ) or negative (controls; $43.5 \pm 25.3 \mathrm{~mm}$, $n=186$ ) for QPX infections ( $t$-test, $P=0.197 ; 37$ of the samples did not include data for size of clams tested).

\section{Clam Sex}

In evaluating the compiled data set, the effects of sex or sex ratio were not included for the overall analysis because there were not enough reports (only 20 out of 313 ) that included this information. In evaluating the data from Rhode Island (Table 2) there was no significant difference between the counts of male, female, and unknown clams, with and without QPX infections $\left[\chi^{2},(2, n=378)=0.96, P=0.62\right]$.

\section{Sample Type}

QPX infections occurred in samples of clams obtained from both cultured clam beds and wild populations. In the compiled data set, there were more samples from cultured beds $(n=197)$ than wild populations $(n=116)$. There was a similar number of controls (i.e., QPX negative samples) among samples collected from cultured beds $(n=119)$ and wild populations $(n=92)$, but more cases (i.e., QPX positive samples; $n=78$ ) and a higher percentage of cases $(76.5 \%)$ came from cultured clam beds compared with wild populations $(n=24,23.5 \%)$. In addition, for QPX positive samples (cases only, $n=102$ ), samples from cultured beds had a significantly higher prevalence $(29.2 \pm$ $27.2 \%$ ) of QPX infections compared with samples from wild populations $(9.6 \pm 9.6 \%$; $t$-test on logit transformed data, $P=$ $0.017)$. The mean size (length) of clams in samples collected from cultured clam beds (Fig. 1, solid vertical line) was significantly smaller than the mean size of clams in samples from wild populations $(35.1 \pm 16.5 \mathrm{~mm}$ versus $59.8 \pm 22.4 \mathrm{~mm}$; $t$-test, $P<0.001)$.

\section{Geographic Distribution}

The frequencies (i.e., counts; data not shown) and the percentages (Fig. 2A) of QPX cases and controls varied among the three Canadian provinces of New Brunswick (NB), Nova 


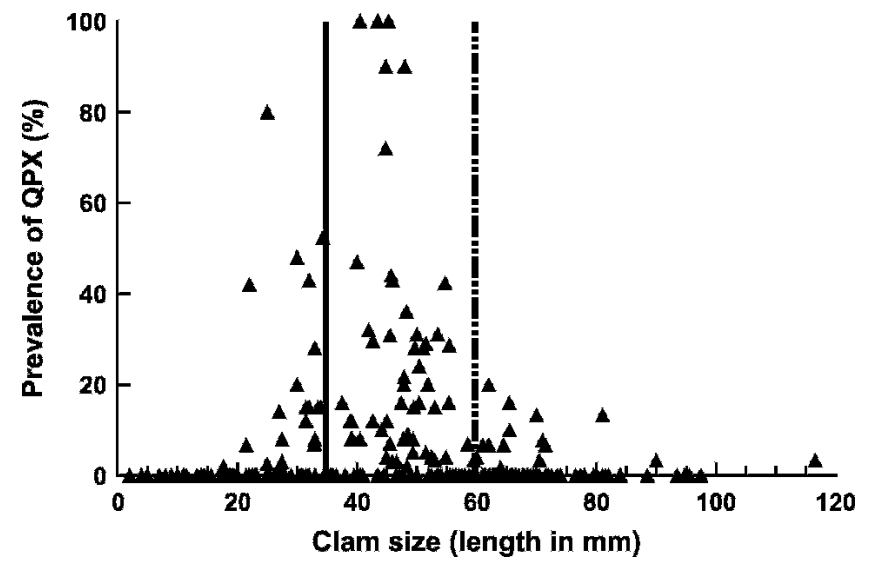

Figure 1. Samples with clams of an intermediate size range (20-55 mm) appear to have the highest prevalence of QPX. The solid vertical line indicates the mean size of clams from all samples (cases and controls) tested from cultured clam beds $(35 \mathrm{~mm})$, whereas the dashed vertical line indicates the mean size of clams tested from wild populations $(60 \mathrm{~mm})$, suggesting QPX infections in smaller, wild clams may be going undetected.

Scotia (NS), and Prince Edward Island (PEI) and the six US states of Massachusetts (MA), Rhode Island (RI), Connecticut (CT), New York (NY), New Jersey (NJ), and Virginia (VA) where outbreaks of QPX disease have occurred. There was a
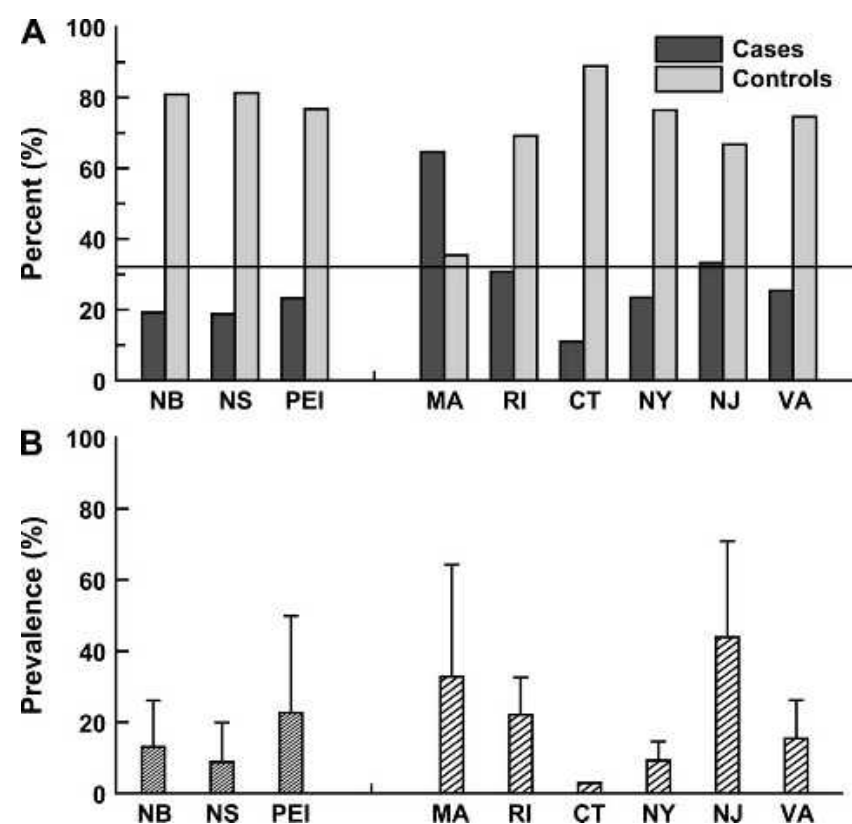

Figure 2. (A) The percent of cases (darker bars) and controls (lighter bars) varied for the three Canadian provinces of New Brunswick (NB), Nova Scotia (NS), and Prince Edward Island (PEI) and the six U.S. states of Massachusetts (MA), Rhode Island (RI), Connecticut (CT), New York (NY), New Jersey (NJ), and Virginia (VA) where outbreaks of QPX disease have occurred. The expected percentage of cases (horizontal line) under the null hypothesis of an even distribution among locations was $32.2 \%$. There was a significant peak in percent of cases from MA locations where QPX has been a substantial problem for more than $10 \mathrm{y}$. (B) The mean prevalence of QPX infections also varied with location, with only marginally significant differences among locations. significant peak in percent of cases from MA locations where QPX has been a substantial problem for more than $10 \mathrm{y}\left[\chi^{2}(8\right.$, $n=311)=42.8, P<0.001]$. The mean prevalence of QPX infections also varied with location (Fig. 2B), with marginally significant differences among locations (ANOVA on logit transformed data, $P=0.071)$. New Jersey and MA recorded the highest mean percent prevalences of QPX, but overall there was no latitudinal gradient. Consequently, results from the three Canadian provinces were combined and compared with those of six U.S. states. Overall, the frequency of cases from American locations was higher than that from Canadian locations $\left[\chi^{2}(1, n=311)=11.0, P=0.001\right]$ with more cases $(n=78)$ and a higher percentage of cases $(76.5 \%)$ coming from American locations compared with Canadian locations $(n=24$, $23.5 \%$ ). This result is driven by the data from MA (i.e., if MA data are removed from the analysis, there is no significant difference between American and Canadian locations, $\left[\chi^{2},(1\right.$, $n=248)=0.98, P=0.32$ ]. Samples from American locations were also more often from cultured clam beds $(90.9 \%)$ compared with the samples from Canadian locations (only $25.0 \%$ ). The mean size of clams in QPX positive samples from American locations was significantly smaller than the mean size of clams in QPX positive samples from Canadian locations $(40.8 \pm 17.3 \mathrm{~mm}$ versus $50.3 \pm 27.5 \mathrm{~mm}$; $t$-test, $P=0.001)$. For samples positive for QPX infections (cases only, $n=102$ ), the mean prevalence of QPX was significantly higher in samples from American locations compared with Canadian locations $(27.5 \pm 26.8 \%$ versus $15.2 \pm 18.7 \%$, $t$-test on logit transformed data, $P=0.02$ ).

\section{Seasonal Patterns}

The frequencies (data not shown) and percentages (Fig. 3A) of cases and controls varied among months of testing. Higher than expected counts of QPX cases were recorded in seven months, with April and December having the largest differences between observed and expected counts $\left[\chi^{2}(11, n=311)=19.1\right.$, $P=0.05]$. When data were pooled into season, there was no statistical evidence of seasonal trends in the counts of cases and controls $\left[\chi^{2}(3, n=311)=4.5, P=0.22\right]$. The mean prevalence of QPX infections also varied by month (Fig. 3B), but there were no significant differences among months (ANOVA on logit transformed data, $P=0.253$ ) or seasons (ANOVA on logit transformed data, $P=0.221$ ).

\section{DISCUSSION}

The primary dependent variable in this study was prevalence of QPX infections in hard clams (= northern quahog), Mercenaria mercenaria. Prevalence (percent positive) data without matching mortality rates or case-fatality data are difficult to interpret because high or rapid QPX-related mortalities preceding sample collection would yield a relatively low estimate of prevalence. Indeed, some of the variation in prevalences of QPX in the compiled data set is expected to be due, in part, to mortality events, because samples were often collected in response to noticeable mortality in the field. As a result, the prevalence data in this analysis should be viewed as conservative values.

Using epidemiological terms, the data available for this analysis were in a case-control format (i.e., data were categorized based on the presence or absence of the organism, which causes QPX disease). Comparing the characteristics of the case 

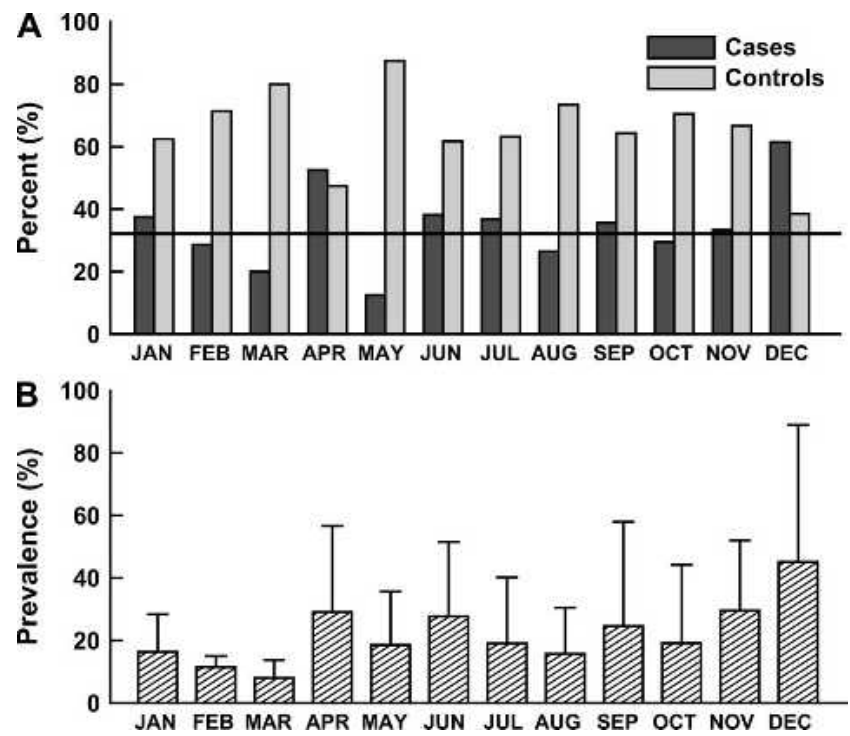

Figure 3. (A) The percentage of cases (darker bars) and controls (lighter bars) varied for each month. The expected percentage (horizontal line) under the null hypothesis of an even distribution among months tested was $32.2 \%$. Seven months have a higher than expected percentage of positive results with the largest differences recorded in April and December. The smallest percentage of positive results was recorded in May. (B) Mean prevalence of QPX infections also varied by month, but because of the high variability, no gradients were discernable. When month was regrouped by season, no evidence for seasonal trends was detected.

samples to those of the control samples highlights potential factors associated with the clams contracting QPX disease. Comparing the prevalence within the case samples identifies potential factors associated with the severity of the disease in the samples. Neither comparison implies a causal relationship, but rather is used to identify testable hypotheses for future research. Factors of potential interest included clam size, age, sex, strain, density, and environmental variables such as location, season, temperature, salinity, dissolved oxygen, turbidity, food supply, water depth, and substrate type. Data for most of these factors were not available. Factors included in this evaluation were mean size of clams, type of sample (from cultured beds or wild populations), location (also grouped by Canada or United States), and month of testing (also grouped by season). Sex ratios were only evaluated for the new data from Rhode Island.

\section{Host Demographics}

\section{Clam Size and Age}

Clam size is related to both the age of the clams and the growing conditions and is an indirect measure of how long the clams have been exposed to environmental variables. Literature values for the relationship between QPX infections and clam size vary. Ford et al. (1997) examined over 2000 hatchery-raised seed clams and found no evidence of QPX infections in clams (1-20 mm). Initial reports from Whyte et al. (1994) described mortalities in slightly larger juvenile and adult hatchery clams ranging from $15-30 \mathrm{~mm}$. No data on ages were reported by Whyte et al. (1994), but MacCallum and McGladdery (2000) explained that lower growth rates in colder waters would mean the Canadian hard clams were older than similar sized clams from the United States. In MacCallum and McGladdery's 8-y survey of Canadian hard clams, the size range for infected clams was $18-180 \mathrm{~mm}$ in length. The smaller clams $(18-25 \mathrm{~mm})$ with QPX infections had been in the environment for one year and were estimated to be about $1 \frac{1}{2}$ years old (MacCallum \& McGladdery 2000). Ford et al. (1997) examined over 700 hatchery-reared clams that were in the environment for their first year of grow-out ( 9 mo or less) and found no evidence of QPX infections. In the outbreaks of QPX in Massachusetts, clam sizes between " 1 and $1 \frac{1}{2}$ inches in valve width" (approximately $1 \frac{1}{2}$ to $2 \mathrm{y}$ old) incurred the highest rate of mortalities (Smolowitz et al. 1998). Coupling histology and molecular tools for diagnostics, QPX has been detected in at least one 15-mm seed clam (Gast et al. 2006). As diagnostics become increasingly sensitive it is expected that the minimum size of clams that acquire QPX infections will become better defined.

In our analysis, clams of an intermediate size (shell length 20-55 mm) had the highest prevalence of QPX infections. This concurs with field observations that mortality is frequently highest in clams just under market size (Smolowitz et al. 1998). If infection prevalence is related to environmental exposure, then this observation suggests the smaller and larger clams have a lower rate of exposure to the QPX pathogen. For the smaller clams, lower exposure may be because of the comparatively lower particle clearance rates (one measure of suspension feeding; Winter 1978). For the larger clams, lower exposure is more difficult to explain. One possibility is that larger clams are more efficient at selecting, ingesting, and digesting QPX cells, and therefore have lower infection prevalence, because the portals of entry appear to be the mantle and gill, not the digestive track (Smolowitz et al. 1998, Ford et al. 2002).

Alternatively, the observed pattern in QPX prevalence with clam size may be related to the effects of QPX infection on growth. If intermediate size clams with QPX infections do not continue to grow at the same rates as intermediate size clams without QPX infections, then larger clams might have a relatively lower prevalence of QPX infections. Smolowitz et al. (1998) demonstrated that clams with QPX infections had a lower condition index and lower shell length increases (i.e., lower signs of new growth) than clams without signs of QPX infections. Clams with QPX infections were also more likely to have chips and cracks in their shells and be found gaping on the surface, both of which would affect food acquisition and ultimately growth.

Our observation that clams of an intermediate size (i.e., sublegal, below market size) had the highest prevalence of QPX infections raises the concern that some of the environmental surveys may be underestimating the prevalence of QPX in wild clams, because most samples from wild populations had larger (mean $60 \mathrm{~mm}$ ), legal size clams. We recommend that future surveys of wild clams include smaller clams in the $20-55 \mathrm{~mm}$ size range.

\section{Sex of Clams}

QPX infections have been found in both male and female clams (MacCallum \& McGladdery 2000, Dove et al. 2004, Table 2), but only a few reports have evaluated differences in infection prevalence between males and females. Sex of an individual clam cannot always be determined from a histological slide, therefore results for sex ratios are usually reported as 
the number of males, females, and unknowns. In both their diagnostic (1991-96) and season surveys (1996-97), MacCallum and McGladdery (2000) observed no significant correlation between QPX infection and sex of clams. They reported percentages of males, females, and unknowns for clams with QPX infections. In a survey of clams from NY, Dove et al. (2004) also reported no significant differences between QPX infections in male and female clams, but this study did not include the raw data for comparison. In our small subset of data from RI (Table 2), there was also no significant difference between the number of males, females, and unknowns with and without QPX infections.

\section{Sample Type-Cultured Versus Wild}

Although most of the QPX-related mass mortalities have had economic impacts for cultured clam beds (Smolowitz et al. 1996, Smolowitz et al. 1998, Ragone-Calvo et al. 1998, Ford et al. 2002), wild populations of clams have also been affected (Bacon et al. 1999, MacCallum \& McGladdery 2000, Dove et al. 2004). Prevalence of QPX in Canadian wild clams ranged from $3.3-20 \%$ (MacCallum \& McGladdery 2000) and in wild clams from New York averaged 5.8\% with an additional 5.1\% suspected (i.e., characteristic inflammation without QPX cells present in the section evaluated) of infections (Dove et al. 2004). In contrast, Ragone-Calvo et al. (1998) did not find QPX in wild clams in Virginia in their 1996-97 study and no wild clams in samples from Rhode Island were positive for QPX. In our compiled data set, the mean size of clams in samples collected from wild clam populations was significantly larger than the mean size of clams in samples collected from cultured populations. Because samples with clams of an intermediate size range (smaller than the mean size of clams from wild populations) had a significantly higher percent prevalence of QPX, QPX infections in smaller, wild clams may be going untested and consequently underestimated.

In our compiled data set, more than half $(63 \%)$ of all samples were collected from cultured clam beds. This reflects the source of the data, because samples from cultured clams must be screened for diseases prior to movement and are often brought to disease research facilities when aquaculturists are encountering unusually high mortalities in their clam beds. High mortalities in wild clam populations may go unnoticed and therefore unreported. A similar number of controls were found for samples of cultured and wild clams, but a higher percentage of QPX cases came from cultured clam beds. Additionally, the samples of cultured clams had a higher prevalence of QPX infections. This information supports the concept that some aspect of culturing (i.e., density, strain, husbandry, etc.) contributes to the presence and the severity of QPX disease (MacCallum \& McGladdery 2000, RagoneCalvo et al. 2007). Interestingly, QPX occurs in cultured and wild samples unlike other thraustochytrid diseases that appear to be restricted to artificial (e.g., captive, aquaria, and hatcheries) systems (McLean \& Porter 1982, Jones \& O’Dor 1983, Bower 1987).

\section{Clam Strain}

Early anecdotal evidence suggested that some strains of cultured clams were more susceptible to QPX disease than other clam strains (Kraeuter et al. 1998, Ragone-Calvo \& Burreson
2002, Ford et al. 2002). Field studies have shown that southernreared hatchery strains of clams were more susceptible to QPX infections and subsequent mortalities than northern strains when both were grown in northern waters. For example, New Jersey (NJ) clams were significantly less infected than nearby southern-reared clams (Kraeuter et al. 1998); however, NJ clam seed suffered higher rates of QPX-mortalities than MA clam seed in MA waters (Ragone-Calvo \& Burreson 2002, Ragone-Calvo et al. 2007, Smolowitz unpublished data). Ford et al. (2002) demonstrated that clam seed from South Carolina hatcheries were more susceptible to QPX infections (i.e., had higher prevalences and intensities) than clam seed of a similar size and age from $\mathrm{NJ}$ hatcheries when both were planted in adjacent beds (in some cases $<10 \mathrm{~m}$ apart) in NJ waters. Ford et al. (2002) also report a similar observation for a 2001 outbreak of QPX in clams from FL hatcheries suffering higher mortalities when grown in VA waters. Ragone-Calvo et al. (2007) detailed a large, multiyear, multistate, field experiment with five clam strains grown in three states. QPX prevalence ranged from $19-21 \%$ in FL seed stocks and $27-29 \%$ in SC seed stocks, whereas prevalences were $<10 \%$ for clams from MA, VA, and NJ when all 5 strains were grown in VA. Final, cumulative mortality was highest in FL clams (79\%), which was significantly greater than in SC clams $(52 \%)$, which was significantly greater than in clams from VA $(36 \%)$ or MA $(33 \%)$, both of which were significantly greater than in the NJ clams $(20 \%$; i.e., FL $>$ SC $>$ MA and VA $>$ NJ). Logistical problems prevented a multistate comparison; nonetheless their results indicate that susceptibility to QPX infection varied with clam strain (genotype). It is not known if there is a threshold concentration of QPX, above which all clams (regardless of strain) would acquire QPX infections. Anecdotal data from RI supports the observation that once QPX is established in a location and the clams were under high disease pressure, QPX may affect clams of all strains. There was not enough information in this compiled data set to evaluate differences in QPX prevalence as a function of clam strain, because data for clam strain was typically not available in published reports.

\section{Clam Density}

Another potential explanation for the patterns observed for QPX prevalence and hard clam sizes (described previously) includes the differences in the planting densities of different sized clams in cultured beds. In aquaculture, smaller clams are frequently grown at high densities. Our analysis supports the observation that clam density could be important in the transmission of the QPX pathogen once it is established in a clam bed (Kraeuter et al. 1998, MacCallum \& McGladdery 2000, Ford et al. 2002). Additionally, clam beds with larger, legal-sized clams are more actively harvested resulting in a reduction in density and the removal of potentially infected individuals. Planting densities have generally been suspected in influencing the susceptibility of cultured hard clams to QPX infection, but published reports have not detected a statistically significant effect of planting density on mortality caused by QPX disease (Kraeuter et al. 1998, Ford et al. 2002). Ford et al. (2002) documented a significant positive correlation between clam density and intensity of QPX infection in a one year experimental planting study, but their experiments did not demonstrate density effects on other measured parameters. The 
inherent variability that occurs in all large-scale field experiments may have lead to the inconclusive results. Future experiments focusing on density will be important to finding strategies to minimize the effects of QPX disease, especially in cultured clam beds.

\section{Environmental Considerations}

\section{Geographic Distribution}

The range of clam mortalities from QPX disease is Atlantic Canada to coastal Virginia; however, differences in the manifestation of the disease have been noted between Canada and the United States (particularly Massachusetts and Virginia, Smolowitz et al. 1998, Ragone-Calvo et al. 1998, Bower \& McGladdery 2003). Because our analysis did not detect a latitudinal gradient in the frequency or prevalence of QPX infections, data from the three Canadian provinces and the six U.S. states were grouped to evaluate differences. The mean prevalence of QPX infections was higher in American samples, where QPX disease continues to plague shellfish growers, especially in MA waters. The mean size of clams from American samples was also smaller because most of the American samples were from cultured clam beds. The comparisons of Canadian samples and American samples should be interpreted with caution because, as indicated previously, the prevalence of QPX infections may be underestimated for clam samples from Canada, because many of the samples included clams of a larger, legal size. More detailed data from each region is needed to further assess this pattern, but the overall lack of larger-scale latitudinal trends suggests that smaller-scale factors may be more important in determining the local distribution of QPX disease.

\section{Temperature and Salinity}

Environmental conditions might play a critical role in determining rates of QPX infections and mortalities. Both temperature (Brothers et al. 2000) and salinity (Brothers et al. 2000, Camara et al. 2004) have been suggested to influence infection rates by affecting the physiology and ecology of both the host bivalve and the pathogenic thraustochytrid. Only a few of the published studies included environmental data. RagoneCalvo et al. (1998) reported detecting QPX in clams from shallow, high-salinity, barrier islands and marshes (30-34 ppt) and not in moderate salinity (15-25 ppt) areas. MacCallum and McGladdery (2000) reported detecting QPX in clams from Canadian sites of moderate to high salinities (20-32 ppt). Ragone-Calvo and Burreson (2002) deployed experimental clams in enzootic waters (28-33 ppt), many of which contracted QPX infections. MacCallum and McGladdery (2000) published temperature and salinity values for the time of collection, but did not find any correlations. For future surveillance efforts, temperature and salinity records for months prior to collection of animals may be preferable, because infections would occur before the testing dates.

\section{Water Depth and Substrate Type}

QPX infections have been documented in clam samples from both intertidal and subtidal sites, and from both muddy and sandy substrates. Smolowitz et al. (1998) reported dead and dying clams from sandy, intertidal aquaculture lease sites in Massachusetts. As a result of the many sand granules lodged between the shells of recently dug clams, the authors reported the "obvious grinding, crunching sound" as clams attempted to close their shells. Ford et al. 2002, manipulated clam planting density at two water depths (subtidal and intertidal) in NJ. They found that intertidal clams (sandy substrates) were more severely affected by QPX disease than the subtidal clams (muddy substrates). In the Ragone-Calvo et al. (2007) field experiments all groups of naïve clams grown in both lowintertidal muddy and intertidal sandy sediments obtained some level of QPX infection. Likewise, MacCallum and McGladdery (2000) detected QPX in intertidal and subtidal clam samples from Canada, and Dove et al. (2004) found QPX in wild, subtidal populations of clams in Raritan Bay, NY. Based on the limited information available, substrate type does not appear to influence presence of QPX infections in hard clams, but more environmental samples from different sediment types are needed to determine if the distribution of QPX in the environment is affected by substrate type.

\section{Seasonality-Month of Testing}

The percentage of samples that were positive for QPX showed signs of a seasonal trend with peaks in April and December. Although this suggests the presence of QPX infections is highest in the spring and winter, it is not known how long it takes clams to acquire infections; therefore this does not yield information on when clams are obtaining infections in the field. Prior results suggest it takes at least 3 mo in the laboratory (Smolowitz et al. 2001) and over nine months in the field (Ford et al. 2002) for naïve clams to contract QPX infections. Similarly, Ragone-Calvo and Burreson (2003) noted QPX infections were not detected until 14 mo after planting naïve clams in the experimental field plots. In our compiled data set there is an interesting trend in the spring months. First, the transition from a low percentage of positive results in March to a peak in April, suggesting many new infections or an increase in the severity of infections to detectable levels occurred during that time frame. Then from April to May there was a large dip in the percent of cases suggesting high clam mortalities may have occurred within that period. Other dips in prevalence, most notably, from July to August may also be signs of mortality events. Data for QPX-related mortalities were not available but Ragone-Calvo et al. (2007) showed prevalence of QPX was correlated with mortality in experimental plots of clams. In our analysis, because of the high variability among months, significant seasonal trends were not discernable for mean prevalence of QPX infections. This may be because of interannual variation masking true month to month differences. Nevertheless, this data suggests that clams acquire QPX infections throughout the year (based on frequency of cases), but once the infections are established then season, along with other factors such as size, strain, or density, may influence the progression of the disease ultimately determining the severity in a group of clams (based on percent prevalence).

For Canadian samples, MacCallum and McGladdery (2000) showed the highest prevalences of QPX infections were recorded in the summer (August). For American samples, Ragone-Calvo et al. (1998) found the highest prevalence in the spring (May). In Table 1, the highest recorded prevalences $(100 \%)$ occurred in samples tested in June and December. Overall, our analysis found no seasonal trend in QPX prevalence 
by location, month, or season. Nevertheless, observational data suggest seasonal patterns in QPX-related mortalities (Kraeuter et al. 1998, Smolowitz et al. 1998) and these cycles of prevalence and mortality should be evaluated further. Data on QPX prevalence alongside mortality and case-fatality rates will be critical in addressing seasonality of this disease.

\section{EPIZOOTIOLOGICAL SUMMARY}

Total prevalence of QPX infections varied from $0-100 \%$. Nonzero values ranged from $1.7 \%$ in a sample of wild clams from Nova Scotia to $100 \%$ in a sample of cultured clams from Massachusetts.

Sizes of clams tested for QPX varied from $1 \mathrm{~mm}$ to $180 \mathrm{~mm}$. QPX prevalence was highest in samples of intermediate sized clams $(\sim 20-55 \mathrm{~mm})$.

QPX infections occurred in both male and female clams.

QPX infections occurred in clams from subtidal and intertidal habitats.

QPX infections occurred in clams from both muddy and sandy environments.

QPX infections occurred in clams collected from both cultured beds and wild populations, but a higher percentage of QPX cases came from cultured beds.

Samples of clams collected from cultured beds contained clams that were smaller in average size (shell length) and had a higher prevalence of QPX infections compared with samples of clams collected from wild populations.
QPX-related clam mortalities were reported from Canada to Virginia; however no latitudinal gradients in QPX prevalence or frequency were found when evaluated for 3 Canadian provinces and 6 U.S. states.

The prevalence of QPX infections was higher in American samples (specifically Massachusetts) where QPX continues to plague shellfish growers.

High percentages of QPX cases were documented in April and December.

Because of high variability, no seasonal trends in QPX prevalence were found when prevalence was evaluated by type (wild versus cultured), month tested, season, location, or country.

\section{ACKNOWLEDGMENTS}

The authors thank S. Shumway, G. MacCallum, G. McManus, and two anonymous reviewers for comments on the manuscript and A. Ganz, D. Erkan, J. Gomez-Leon, K. Markey, and Coastal Fellows J. Lucia and A. Novia for help in sample collection and processing for Rhode Island samples. This work was funded by a National Science Foundation Graduate Fellowship to M. Lyons, and partially funded by an Ecology of Infectious Disease Grant (EF 0429004) to R. S. and J. E. W. Surveys in Rhode Island were funded by the Rhode Island Aquaculture Initiative and the Rhode Island Department of Environmental Management, Fish and Wildlife.

\section{LITERATURE CITED}

Archambault, M., V. M. Bricelj, J. Grant \& D. M. Anderson. 2004. Effects of suspended and sedimented clays on juvenile hard clams, Mercenaria mercenaria, within the context of harmful algal bloom mitigation. Mar. Biol. 144:553-565.

Anderson, R. S., B. S. Kraus, S. E. McGladdery, K. S. Reece \& N. A Stokes. 2003. A thraustochytrid protist isolated from Mercenaria mercenaria: molecular characterization and host defense responses. Fish Shellfish Immuno. 115:183-194.

Azevedo, C. \& L. Corral. 1997. Some ultrastructural observations of a thraustochytrid (Protoctista, Labyrinthulomycota) from the clam Ruditapes decussates (Mollusca, Bivalvia). Dis. Aquat. Org. 31:73-78.

Bacon, G. S., S. E. McGladdery \& B. A. MacDonald. 1999. Quahog Parasite X ("QPX") of hard-shell clams, Mercenaria mercenaria and M. mercenaria var. notata in Atlantic Canada-observations from wild and cultured clams. J. Shellfish Res. 18:295.

Brothers, C., E. Marks \& R. Smolowitz. 2000. Conditions affecting the growth and zoosporulation of the protistan parasite QPX in culture. Biol. Bull. 199:200-201.

Bower, S. M. 1987. The life cycle and ultrastructure of a new species of thraustochytrid (Protozoa: Labyrinthomorpha) pathogenic to small abalone. Aquaculture 67:269-270.

Bower, S. M. \& S. E. McGladdery. 2003. Synopsis of infectious diseases and parasites of commercially exploited shellfish. http://www-sci. pac.dfo-mpo.gc.ca/shelldis/title_e.htm.

Camara, M. D., L. M. Ragone-Calvo, R. B. Carnegie \& S. K. Allen. 2004. Line-crossing within and among five commercial strains of hard clams, Mercenaria mercenaria: Growth, survival, and susceptibility to QPX disease at differing salinities. J. Shellfish Res. 23:283-284.

DeCrescenzo, J., I. Sunila, J. Karolus \& J. Volk. 1999. Histopathological survey of the Quahog, Mercenaria mercenaria, along the Connecticut coastline. J. Shellfish Res. 18:264.
Dove, A., P. R. Bowser \& R. M. Cerrato. 2004. Histological analysis of an outbreak of QPX disease in wild hard clams Mercenaria mercenaria in New York. J. Aquat. Anim. Health 16:246-250.

Drinnan, R. E. \& E. B. Henderson. 1963. 1962 mortalities and a possible disease organism in Nequac Quahogs. Annual Report No. B11, Biological Station, St. Andrews. New Brunswick.

Ford, S. E., J. N. Kraueter, R. D. Barber \& G. Mathis. 2002. Aquaculture-associated factors in QPX disease of hard clams: density and seed source. Aquaculture 208:23-38.

Ford, S. E., R. Smolowitz, L. M. Ragone-Calvo, R. Barber \& J. N. Kraueter. 1997. Evidence that QPX (Quahog Parasite Unknown) is not present in hatchery-produced hard clam seed. J. Shellfish Res. 16:519-521.

Frank, U., C. Rabinowitz \& B. Rinkevich. 1994. In vitro establishment of continuous cell cultures and cell lines from ten colonial cnidarians. Mar. Biol. 120:491-499.

Fraser, D. (2004) Troubled waters in Wellfleet. Cape Cod Times, December 18, 2004. http://capecodonline.com/cctime/ troublewaters 18.htm.

Gast, R. J., E. Cushman, D. M. Moran, K. R. Uhlinger, D. Leavitt \& R. Smolowitz. 2006. DGGE-based detection method for Quahog Parasite Unknown (QPX). Dis. Aquat.Org. 70:115-122.

Gast, R. J., D. M. Moran, C. Audemard, M. M. Lyons, J. Defaveri, K. S. Reese, D. Leavitt \& R. Smolowitz. Environmental distribution and persistence of Quahog Parasite Unknown (QPX). Submitted to. Dis. Aquat. Org. (submitted).

Hickey, J. M., D. F. Leavitt \& R. Smolowitz. 2002. Quahog parasite unknown (QPX) fact sheet. Massachusetts Division of Marine Fisheries and the South Eastern Massachusetts Aquaculture Center, Barnstable County, MA.

Howard, D. W., E. J. Lewis, B. J. Keller \& C. S. Smith. 2004. Histological techniques for marine bivalve mollusks and crustaceans. NOAA Technical Memorandum NOS NCCOS 5:218 pp. 
Ilan, M., H. Contini, S. Carmeli \& B. Rinkevich. 1996. Progress towards cell cultures from a marine sponge that produces bioactive compounds. J. Mar. Biotechnol. 4:145-149.

Jones, G. M. \& R. K. O'Dor. 1983. Ultrastructural observations on a thraustochytrid fungus parasitic in the gills of squid (Illex illecebrosus Lesueur). J. Parasitol. 69:903-911.

Kleinschuster, S. J., R. Smolowitz \& J. Parent. 1998. In vitro life cycle and propagation of Quahog Parasite Unknown. J. Shellfish Res. 17:75-78.

Kraeuter, J. N., S. E. Ford, R. Barber \& G. Mathis. 1998. Effects of planting density and depth on proliferation of QPX in hard. J. Shellfish Res. 17:358.

Lyons, M. M., J. E. Ward, R. Smolowitz, K. R. Uhlinger \& R. J. Gast. 2005. Lethal marine snow: pathogen of bivalve mollusc concealed in marine aggregates. Limnol. Oceanogr. 50:1983-1988.

Lyons, M. M., R. Smolowitz, C. F. Dungan \& S. B. Roberts. 2006. Development of a real time quantitative PCR assay for the hard clam pathogen, quahog parasite unknown (QPX). Dis. Aquat. Org. 72:45-52.

Maas, P. A. Y., S. J. Kleinschuster, M. J. Dykstra, R. Smolowitz \& J. Parent. 1999. Molecular characterization of QPX (quahog parasite unknown), a pathogen of Mercenaria mercenaria. J. Shellfish Res. 18:561-567.

MacCallum, G. S. \& S. E. McGladdery. 2000. Quahog parasite unknown (QPX) in the northern Quahog Mercenaria mercenaria (Linnaeus, 1758) and $M$. mercenaria var. notata from Atlantic Canada, survey results from three maritime provinces. J. Shellfish Res. 19:43-50.

McLean, N. \& D. Porter. 1982. The yellow-spot disease of Tritonia diomedea Bergh, 1894 (Mollusca: Gastropoda: Nudibranchia): encapsulation of the thraustochytriaceous parasite by host amoebocytes. J. Parasitol. 68:243-252.

Miller, J. D. \& E. B. G. Jones. 1983. Observations on the association of thraustochytrid marine fungi with decaying seaweed. Bot. Mar. 26:345-352.

Naganuma, T., H. Takasugi \& H. Kimura. 1998. Abundance of thraustochytrids in coastal plankton. Mar. Ecol. Prog. Ser. 162:105-110.

Polglase, J. L. 1980. A preliminary report on the thraustochytrid(s) and labyrinthulid(s) associated with a pathological condition in the lesser octopus Eledone cirrhosa. Bot. Mar. 23:699-706.

Ragan, M. A., G. S. MacCallum, C. A. Murphy, J. J. Cannone, R. R. Gutell \& S. E. McGladdery. 2000. Protistan parasite QPX of hardshell clam Mercenaria mercenaria is a member of Labyrinthulomycota. Dis. Aquat. Org. 42:185-190.

Raghukumar, S. 1988. Detection of the thraustochytrid protist Ulkenia visurgensis in a hydroid, using immunofluorescence. Mar. Biol. 97:253-258.

Raghukumar, S. 2002. Ecology of the marine protists, the Labyrinthulomycetes (thraustochytrids and labyrinthulids). Eur. J. Protistol. 38:127-145.

Raghukumar, S. \& C. Raghukumar. 1999. Thraustochytrid fungoid protists in faecal pellets of the tunicate Pegea confoederata, their tolerance to deep-sea conditions and implications in degradation processes. Mar. Ecol. Prog. Ser. 190:133-140.

Raghukumar, S., C. Raghukumar \& A. Rajendran. 1990. Abundance of thraustochytrid fungi in the Arabian Sea. Estuar. Coast Shelf Sci. 31:251-358.
Raghukumar, S. \& K. Schaumann. 1993. An epifluorescence microscopy method for direct detection and enumeration of the fungi-like marine protists, the thraustochytrids. Limnol. Oceanogr. 38:182187.

Ragone-Calvo, L. M. \& E. M. Burreson. 2002. QPX susceptibility in Hard Clams varies with geographic origin of brood stock. Virginia Institute of Marine Science Resource Advisory No. 74 (VSG-02-18).

Ragone-Calvo, L. M. \& E. M. Burreson. 2003. Variation in QPX susceptibility with host genetic origin. J. Shellfish Res. 22:291.

Ragone-Calvo, L. M., J. G. Walker \& E. M. Burreson. 1997. Occurrence of QPX, quahog parasite unknown in Virginia hard clams, Mercenaria mercenaria. J. Shellfish Res. 16:334.

Ragone-Calvo, L. M., J. G. Walker \& E. M. Burreson. 1998. Prevalence and distribution of QPX, Quahog Parasite Unknown, in hard clams Mercenaria mercenaria in Virginia, USA. Dis. Aquat. Org. 33:209-219.

Ragone-Calvo, L. M., G. M. Burreson, S. E. Ford, J. N. Kraeuter, D. F. Leavitt \& R. Smolowitz. 2003. Host genetic origin an important determinant of QPX disease. J. Shellfish Res. 22:322.

Ragone-Calvo, L. M., S. E. Ford, J. N. Kraeuter, D. F. Leavitt, R. Smolowitz \& E. M. Burreson. 2007. Influence of host genetic origin and geographic location on QPX disease in hard clams, Mercenaria mercenaria. J. Shellfish Res. 26:1-11.

Santangelo, G., L. Bongiorni \& L. Pignataro. 2000. Abundance of thraustochytrids and ciliated protozoans in a Mediterranean sandy shore determined by an improved, direct method. Aquat. Microb. Ecol. 23:55-61.

Smolowitz, R. \& D. Leavitt. 1997. Quahog Parasite Unknown (QPX): an emerging disease of hard clams. J. Shellfish Res. 16:335-336.

Smolowitz, R., D. Leavitt \& F. Perkins. 1996. An important new disease of hard clams, Mercenaria mercenaria, in the Northeast United States. J. Shellfish Res. 15:460-461.

Smolowitz, R., D. Leavitt \& F. Perkins. 1998. Observations of a Protistan disease similar to QPX in Mercenaria mercenaria (Hard Clams) from the coast of Massachusetts. J. Invertebr. Pathol. 71:9-25.

Smolowitz, R., D. Leavitt, B. Lancaster, E. Marks, R. Hanselmann \& C. Brothers. 2001. Laboratory based transmission studies of quahog parasite unknown (QPX) in Mercenaria mercenaria. J. Shellfish Res. 20:555-556.

Sparrow, F. K. 1936. Observations on the marine fungi of Woods Hole waters. Biol. Bull. 70:236-273.

Stokes, N. A., L. M. Ragone-Calvo, K. S. Reece \& E. M. Burreson. 2002. Molecular diagnostics, field validation, and phylogenetic analysis of Quahog Parasite Unknown (QPX), a pathogen of the hard clam Mercenaria mercenaria. Dis. Aquat. Org 52:233-247.

Sunila, I. 2006. Connecticut's hard clam industry and QPX-disease. J. Shellfish Res. 25:780.

Thorsen, M. S. 1999. Abundance and biomass of the gut-living microorganisms (bacteria, protozoa and fungi) in the irregular sea urchin Echinocardium cordatum (Spatangoida: Echinodermata). Mar. Biol. 133:353-360.

Whyte, S. K., R. J. Cawthorn \& S. E. McGladdery. 1994. QPX (Quahaug Parasite X), a pathogen of northern quahaug Mercenaria mercenaria from the Gulf of St. Lawrence, Canada. Dis. Aquat. Org. 19:129-136.

Winter, J. E. 1978. A review on the knowledge of suspension-feeding in lamellibranchiate bivalves, with special reference to artificial aquaculture systems. Aquaculture 13:1-33. 